OPEN ACCESS

Edited by:

Lawrence Toll,

Florida Atlantic University,

United States

Reviewed by:

Gavril Pasternak,

Memorial Sloan Kettering Cancer

Center, United States

Kabirullah Lutfy,

Western University of Health

Sciences, United States

${ }^{*}$ Correspondence:

Wendy M. Walwyn

wwalwyn@g.ucla.edu

tThese authors have contributed equally to this work.

Specialty section: This article was submitted to Psychopharmacology, a section of the journal

Frontiers in Psychiatry

Received: 06 December 2017 Accepted: 21 March 2018

Published: 23 April 2018

Citation:

Severino AL, Shadfar A, Hakimian JK, Crane O, Singh G, Heinzerling K and Walwyn WM (2018) Pain Therapy Guided by Purpose and Perspective in Light of the Opioid Epidemic.

Front. Psychiatry 9:119. doi: 10.3389/fpsyt.2018.00119

\section{Pain Therapy Guided by Purpose and Perspective in Light of the Opioid Epidemic}

\author{
Amie L. Severino $0^{1,2,3,4 t}$, Arash Shadfar ${ }^{5 t}$, Joshua K. Hakimian ${ }^{1,4}$, Oliver Crane ${ }^{1,4}$, \\ Ganeev Singh ${ }^{1,4}$, Keith Heinzerling ${ }^{6}$ and Wendy M. Walwyn ${ }^{1,4 *}$ \\ ${ }^{1}$ Department of Psychiatry and Biobehavioral Sciences, David Geffen School of Medicine at the University of California Los \\ Angeles, Los Angeles, CA, United States, ${ }^{2}$ Vatche and Tamar Manoukian Division of Digestive Diseases, Department of \\ Medicine, David Geffen School of Medicine at the University of California Los Angeles, Los Angeles, CA, United States, \\ ${ }^{3}$ Veteran Affairs Greater Los Angeles Healthcare System, Los Angeles, CA, United States, ${ }^{4}$ UCLA Brain Research Institute, \\ Los Angeles, Los Angeles, CA, United States, ${ }^{5}$ Department of Psychiatry, Western University of Health Sciences, Pomona, \\ CA, United States, ${ }^{6}$ Department of Family Medicine, David Geffen School of Medicine at the University of California, \\ Los Angeles, CA, United States
}

Prescription opioid misuse is an ongoing and escalating epidemic. Although these pharmacological agents are highly effective analgesics prescribed for different types of pain, opioids also induce euphoria, leading to increasing diversion and misuse. Opioid use and related mortalities have developed in spite of initial claims that OxyContin, one of the first opioids prescribed in the USA, was not addictive in the presence of pain. These claims allayed the fears of clinicians and contributed to an increase in the number of prescriptions, quantity of drugs manufactured, and the unforeseen diversion of these drugs for non-medical uses. Understanding the history of opioid drug development, the widespread marketing campaign for opioids, the immense financial incentive behind the treatment of pain, and vulnerable socioeconomic and physical demographics for opioid misuse give perspective on the current epidemic as an American-born problem that has expanded to global significance. In light of the current worldwide opioid epidemic, it is imperative that novel opioids are developed to treat pain without inducing the euphoria that fosters physical dependence and addiction. We describe insights from preclinical findings on the properties of opioid drugs that offer insights into improving abuse-deterrent formulations. One finding is that the ability of some agonists to activate one pathway over another, or agonist bias, can predict whether several novel opioid compounds bear promise in treating pain without causing reward among other off-target effects. In addition, we outline how the pharmacokinetic profile of each opioid contributes to their potential for misuse and discuss the emergence of mixed agonists as a promising pipeline of opioid-based analgesics. These insights from preclinical findings can be used to more effectively identify opioids that treat pain without causing physical dependence and subsequent opioid abuse.

Keywords: biased agonism, pharmacokinetics, opioid epidemic, chronic pain, opioid use disorder, oxycodone, mixed agonists 


\section{OXYCODONE AND OXYCONTIN AT THE CENTER OF THE PRESCRIPTION OPIOID EPIDEMIC}

\section{The History of Oxycodone Treatment of Chronic Non-Cancer Pain}

Oxycodone, a semisynthetic opioid, was first formulated in 1916 from thebaine, a chemical found in opium poppy plants. The drug was first marketed as a less addictive alternative to "narcotic" drugs, such as morphine and heroin, which were typically prescribed to patients as an analgesic in the early 1900s. Oxycodone was first released in the USA in 1939 by Merck as a combination drug containing scopolamine, oxycodone, and ephedrine, but was discontinued in 1987 (1). Purdue Pharma then developed an extended-release formulation of oxycodone, called OxyContin. The FDA approved OxyContin in 1995 (2), noting that the reduced frequency of dosing was the only advantage of OxyContin over regular oxycodone (3). This drug was aggressively marketed by Purdue Pharma for opioid-based management of moderate-to-severe cancer and non-cancer pain where the use of an opioid analgesic was considered appropriate for more than a few days (2). Purdue used an aggressive marketing strategy to target-specific physicians (4), particularly those with less time to evaluate patients and often with less training in pain-management techniques. This led to more than half of the total OxyContin prescriptions being written by primary care physicians rather than pain specialists (4). In addition, direct-toconsumer pharmaceutical advertising, allowed only in the USA and New Zealand, has contributed to mass consumer awareness of the availability of these drugs with a demonstrated influence on the prescribing practice of physicians $(5,6)$. This aggressive physician directed marketing, as well as direct-to-consumer marketing, has become a benchmark for the marketing of opioids.

\section{The Financial Incentive for Prescription Opioid Distribution}

The Purdue-Frederick company first marketed MsContin (morphine sulfate) as an extended-release opioid-containing formula to treat pain in terminal cancer patients. MsContin generated $\$ 475$ million in sales over a decade. After the Sackler brothers acquired Purdue-Frederick and rebranded the company as Purdue Pharma, they released OxyContin, which generated \$45 million in sales in just the first year after its release in 1996. By 2001, the annual revenue from OxyContin sales reached $\$ 1.1$ billion and rose to $\$ 2.528$ billion by 2014 in the USA alone.

Currently, the Purdue Pharma company is $100 \%$ owned by members of the Sackler family, who are worth $\$ 13$ billion and ranked as the 19th wealthiest family in the USA in 2016 (7). In addition to Purdue Pharma and other Sackler holdings, there are several other companies manufacturing oxycodone and related opioid compounds to fill the 259 million annual prescriptions written to patients in the USA, generating an additional $\$ 11$ billion in opioid sales annually in 2011 (8). These include Abbot Labs, Novartis, Teva, Pfizer, Endo Pharmaceuticals, Impax, Actavis, Sandoz, Janssen Pharmaceuticals, etc. Together, these figures demonstrate the significant financial incentive pharmaceutical companies have to market opioid compounds despite growing concerns of the abuse liability and safety of these drugs.

\section{Recognition of the Abuse Liability of Oxycodone and OxyContin}

OxyContin was marketed as a delayed-release formulation allowing $12 \mathrm{~h}$ of continuous analgesia with fewer side effects than other opioid-based analgesics if used as directed. This formulation was promising in that the delayed-release would enable patients to sleep through the night, improving the standard of care for chronic pain patients at the time. However, this drug has been widely misused for non-medical purposes. At the time of the release of OxyContin in 1996, it was already known that $68 \%$ of an OxyContin tablet could be extracted by crushing the tablet (4). Since the first published reports of OxyContin abuse in 2000 (9), public awareness of its abuse liability has grown. Indeed, Purdue-Frederick, a holding of Purdue Pharma, paid \$470 million dollars in fines to federal and state agencies and $\$ 130$ million of payments in civil suits due to the misbranding of OxyContin as non-addictive in 2007 (10). Three executives of Purdue Pharma also pleaded guilty to OxyContin misbranding charges and paid $\$ 34.5$ million in fines. By early 2017, there were daily reports of the diversion and misuse of prescription opioids with a number of states and counties across the country filing suit against five pharmaceutical companies, including Purdue. The plaintiffs in these suits claimed that the aggressive marketing campaign of opioid compounds is founded on fraudulent assertions of the safety of these drugs and that this misinformation has contributed to the ongoing opioid crisis. Purdue has responded to these claims by emphasizing that opioids are essential in pain management (2) and that their extended-release abuse-deterrent formulations are evidence of their drive to reduce the diversion of OxyContin (8). In 2018, Purdue stated it will no longer advertise directly to American doctors, a measure that will hopefully reduce overprescription of opioids (11).

\section{The Patterns of Prescription Opioid Misuse and Overdose Mortalities Worldwide}

The incidence of lifetime OxyContin abuse in the USA increased from $0.1 \%$ in 1999 to $0.4 \%$ in 2001 (12). By 2013, over 1,000 Americans were treated daily in emergency departments for prescription opioid misuse and in 2014, 4.3 million people used prescription opioids for non-medical reasons $(13,14)$. This trend was also seen in the number of deaths attributed to oxycodone, which increased from 14 cases in 1998 to 14,000 cases in 2006 and 18,000 in 2015 (15). Although not of the same magnitude and somewhat delayed, this increase in opioid abuse and mortality is also occurring in other countries $(16,17)$. In Australia, oxycodone-related deaths increased sevenfold between 2001 and 2011 (18). In Finland, opioid mortalities increased from 9.5\% of all drug overdose deaths in 2000 to $32.4 \%$ in 2008 (19), and data from Brazil, China, and the Middle East show similar increases in opioid diversion (17). In the United Kingdom, although tramadol and methadone are misused over oxycodone, the pattern of opioid misuse shows a similar increase to the USA albeit 
on a smaller scale (20). While Americans consume $80 \%$ of the global opioid supply and $99 \%$ of the global hydrocodone supply (21) and the number of overdose mortalities is considerably higher in the USA, the opioid epidemic is growing worldwide.

\section{The Most Vulnerable Populations}

The incidence of opioid overdose mortality in the USA shows three hotspots: (1) the Appalachian states of Kentucky, Virginia, West Virginia, Pennsylvania, and Ohio, (2) the Northeast states of Maine, New Hampshire, and Rhode Island, and (3) the Southwest states of Nevada, Utah, New Mexico, and Arizona (15). This could be related to the demographics of these areas and the prescribing habits of the local medical professionals and pharmacies (22-25). Within all of these affected areas, opioid-related deaths are predominately Caucasians of middle age and are a result of drug overdose, alcohol-related disease, suicide, and psychiatric disorders. This has resulted in the first decline in life expectancy in the USA since 1993 (26-29). This has been highlighted in a series of articles that describe this population as subject to the "deaths of despair" $(27,30)$ and a "toxic stress" response to benign early-life events (31).

The primary factor contributing to these "deaths of despair" is the collapse of the white high-school educated working class from its heyday of the 1970s. This population's struggles in the job market in early adulthood became more difficult over time and are accompanied by health and personal issues that contribute to an increased morbidity from chronic pain, and physical and mental health disorders including opioid use disorder [OUD (32)]. The (USA) National Bureau of Economic Research found that for every $1 \%$ increase in unemployment, there is a $3.6 \%$ increase in opioid-related deaths, suggesting that macroeconomic conditions have influence over national drug misuse (33). Considering the global economic aftershocks of the USA's recession, we suggest that global economic recession contributed to the developing international opioid epidemic. To this point, a meta-analysis of research published from 1995 to 2015 in South America, the Caribbean, Europe, Asia, the USA, and Australia suggests that economic depression causes mental health issues that exacerbate illicit drug use (34). Case and Deaton additionally report that the use of prescription opioids did not create the vulnerable American profile, but the ease of availability of these compounds and the difficulty in treating opioid misuse in a depressed economy has inflamed the "sea of despair" that extends across the USA $(27,30)$.

\section{Addressing Chronic Pain in the Midst of the Opioid Epidemic}

It is clear that mass production, marketing, and prescription of opioids for pain treatment has contributed to the opioid epidemic in vulnerable demographics, characterized by mental health disorders, socioeconomic challenges, and susceptibility to occupational injury. We discuss the interplay of mental health, pain, and depression, and how these factors contribute to the misuse and addiction of prescription opioids. One of the key marketing claims of pharmaceutical companies was that the presence of pain is protective against opioid misuse. The evidence for this claim is shockingly limited due to evolving diagnostic criterion for opioid misuse and does not account for the influence of mental health on opioid misuse behavior in the pain state. This gives us perspective toward treating pain with the intent to limit the pro-addiction properties and off-target effects of future pharmaceuticals to decrease opioid dependence in the chronic pain state. We look to insights from behavioral research on addiction and reward, and then to mechanistic research on the pharmacokinetic and signaling properties on opioids to address these issues.

\section{ARE CHRONIC PAIN PATIENTS AT RISK FOR OPIOID MISUSE?}

\section{The Use of Opioids to Treat Chronic Pain}

Opioids are highly effective analgesics for the management of acute pain or pain associated with cancer but it is the opioid treatment of non-cancer pain that is at the root of the opioid epidemic. Before the introduction of OxyContin, patients of all ages suffering from chronic non-cancer pain were commonly under-treated due to a fear of opioid addiction and of other side effects of these drugs (35-37). There were also few viable alternatives, heroin and its metabolite, morphine, had been abused during the Vietnam war and a prevailing public stigma against the use of drugs developed (38). This culminated in an "opioid-phobia" and recurrent under-treatment of pain. Spurred by the promise that the presence of pain protects against opioid addiction in patients with chronic cancer pain (39), the availability of a slow-release opioid (OxyContin) and an aggressive marketing strategy by Purdue, opioid-phobia was replaced by an over-willingness to prescribe opioids. This openness, based on the success of long-term opioid treatment of cancer patients by oncologists and pain specialists (39) was coupled with a lack of adequate physician training in the appropriate use of opioids or evidence for their use in other pain conditions, increasing market pressure and a lack of regulatory control by the government. This timely interplay of multiple factors resulted in the number of opioid prescriptions per 100 persons per year increasing from 61.9 in 2000 to 83.7 in 2009, and to 259 million prescriptions by 2012, almost one per person (40-42). This increase has not been reflected by a change in the percentage of either ambulatory Americans or those reporting to the emergency department in pain, suggesting that the increase in opioid prescriptions is unrelated to the presence or absence of pain $(43,44)$. However, these large scale epidemiological studies make it difficult to assess whether opioid-based treatment of the $\sim 100$ million Americans in pain (45) has influenced the incidence of opioid misuse that affects 4.3 million Americans (14, 46). Assessing the risk of opioid misuse in chronic pain patients provides greater insight into the vulnerability of these patients for addiction.

\section{The Risk of Opioid Misuse in Chronic Pain Patients}

At the center of the opioid epidemic lies an unanswered question as to whether pain is protective of opioid misuse, a claim first made by Purdue in the 1990s. This was based on the findings from two studies that suggested the risk of addiction in pain 
patients was less than $1 \%$ (4). In the first study, Porter and Jick found iatrogenic addiction in 4 of 11,882 patients (47) and in the second, Perry and Heidrich found no addiction among 10,000 burn patients treated with opioids (48). A third study by Portenoy and Foley found no evidence of abuse behaviors in 38 patients treated with different opioids (49). The 5-sentence, 101-word letter to the New England Journal of Medicine in 1980 by Porter and Jick was recently found to have been uncritically cited by 439 authors as proof that addiction was rare in long-term opioid therapy. Despite its limitations, this letter and its citations have made a seminal contribution to the opioid crisis (50).

Before considering the evidence for a protective effect of pain in preventing opioid misuse, the criterion by which to assess opioid misuse must be defined. Initially, opioid dependence and addiction were considered the definitive benchmark. These terms have recently been replaced by the term "opioid misuse" or the use of opioids for any other reason or under any other dosing schedule than originally prescribed. The diagnostic classification system of patients misusing opioids has similarly evolved and the terms "abuse" or "dependence" have been replaced by the diagnosis of OUD. According to the criteria established by the Diagnostic and Standard Manual of Mental Disorders (DSM) V (51), OUD has levels of severity depending on the number of criteria met in several categories. The four categories of criteria that characterize OUD include impaired control, social impairment, risky use, and pharmacological properties (physical tolerance and withdrawal symptoms).

Using these criteria, recent reports clearly show that the incidence of opioid misuse and aberrant drug-related behavior is in fact higher, not lower, in pain patients compared with the general population (52-63). Chronic pain patients have a higher rate of comorbid depression and anxiety, likely contributing to their increased use and misuse of opioids (64). Indeed, 30-80\% of chronic pain patients are concurrently diagnosed with both depression and chronic pain, a comorbidity known as the paindepression dyad $(65,66)$. Both conditions are closely interwoven in that they respond to similar treatments, aggravate or improve each other, and share common biological mechanisms [for review see Ref. (67)]. Using opioids to relieve pain in the presence of this dyad may in itself drive further psychiatric comorbidities (68). This patient population is unsurprisingly more likely to increasingly misuse opioids $(58,63,69-71)$. Patient escalation of opioid doses in response to the progressive interaction between pain and affect or to compensate for tolerance and changes in pain sensitivity over time ("pseudoaddictive" behaviors) (71-73) may explain enhanced aberrant drug-related behaviors in chronic pain patients (61), as well as the positive correlation between baseline pain and the presence of OUD at a 3-year follow-up (74).

\section{WHY ARE OPIOIDS SO ADDICTIVE?}

The motivation to continue taking drugs in spite of adverse consequences can be explained by several concurrent theories. The Opponent Process theory (75) results from a balance between two valuationally opposite components, a loss of function within the reward-mediating dopaminergic circuits and an increased function of stress-related circuitry involving the extended amygdala, the kappa/dynorphin opioid and corticotrophin-signaling systems [reviewed in Ref. (76)]. The latter system becomes hyperactive during opioid dependence and manifests as increased anxiety and aggressive behaviors $(77,78)$. Another, co-occurring theory of the motivation behind continued drug use is the Incentive Sensitization theory that proposes an increase in drug-paired cues with chronic drug taking (79). Together, these systems drive drug-seeking behavior that is a product of (1) a decrease in positive outcome coupled with the promise and pullof drugassociated cues and (2) an increase in dysphoria between drug exposures and during withdrawal (80-82). This is particularly relevant for opioids as these compounds induce a tolerance to repeated exposures of the same dose of the drug. This leads to (1) an escalating intake of opioids over time resulting in compulsive opioid-taking behaviors (83), (2) increasing dependence, and (3) increasing negative affect seen in the absence of the drug (84) that together culminate in further dysregulation of the reward system (85).

The negative affective state of depression and anxiety associated with chronic pain can be relieved temporarily by the analgesic and euphoric properties of acute opioid use, which contributes to their abuse liability in the chronic pain state (86). However, both pain and opioid use create a new homeostasis in the reward and stress-related pathways [reviewed in Ref. (87)], an example of which can be seen in chronic pain patients who misuse opioids and also fail to show a positive affect from natural rewards $(84,88)$. Preclinical studies in rodent models have been able to examine the interaction between pain and opioids at several levels. Pain does not affect the number of low doses of opioid infusions (of heroin, morphine, and oxycodone) earned in a self-administration model of drug-seeking behavior but does increase heroin self-administration to binge levels at higher doses and during prolonged access to the drug (89-93). By contrast, pain reduces the self-administration of fentanyl (94), a shorter-acting but highly efficacious opioid that rapidly crosses the blood-brain barrier (BBB) (95). Pain also increases drug (morphine)-seeking behavior when the drug is no longer available (96). This result suggests that the abuse liability of opioids in the chronic pain state is not directly motivated by analgesia-seeking and intensifies when the drug is no longer available yet drug-associated cues and environmental stimuli are present. Together, these preclinical findings suggests that chronic pain produces a vulnerability to addiction-like behavior, bearing a similarity to the behavior of opioid addicts in chronic pain who are more likely to relapse once tapering off a maintenance buprenorphine naloxone treatment (97).

\section{THE CURRENT CLINICAL TREATMENT OF CHRONIC PAIN PATIENTS WITH OPIOID USE DISORDER}

The current clinical treatment of chronic pain in patients with OUD in the USA relies on 3 FDA-approved medications: buprenorphine naloxone, methadone, and long-acting injectable naltrexone (98). These strategies seek to antagonize or minimize the agonist properties of opioids to reduce the likability of 
opioids. The use of methadone in the USA for OUD is limited to highly restricted methadone programs, but buprenorphine can be prescribed for office-based treatment by certified physicians. Buprenorphine, an opioid partial agonist, has analgesic effects and can be used to treat co-occurring chronic pain and OUD. While outcomes for OUD treatment with buprenorphine are similar for patients with and without chronic pain (99), poorly controlled pain during buprenorphine treatment is a risk for opioid relapse $(97,100,101)$. Buprenorphine combined with naloxone, an opioid antagonist added to reduce diversion of buprenorphine for intravenous abuse, is FDA approved for OUD (e.g., Suboxone ${ }^{\circledR}$ ), while a transdermal formulation (Butrans ${ }^{\circledR}$ ) and a buccal film (Belbuca ${ }^{\circledR}$ ), both without added naloxone, are approved for chronic pain. There are several novel compounds and approaches under development to treat pain, non-opioid compounds such as those that target cannabinoid receptors (102) and non-pharmaceutical, behavioral-based options to treat pain patients (103). However, for patients with chronic pain who continue to prefer a "quick fix from pain pills," the development of analgesic compounds that are not rewarding and have minimal off-target effects remains a challenge in the current context of the opioid epidemic.

\section{NOT ALL OPIOID ANALGESICS ARE THE SAME: EXPLORING NOVEL PHARMACEUTICAL APPROACHES TO GUIDE THERAPEUTIC INTERVENTIONS FOR CHRONIC PAIN}

Opioids have been used for centuries as the treatment of choice for pain but "abuse-deterrent" formulations may decrease opioid misuse and deaths if strategically developed. Abuse-deterrent formulations of existing opioids are one strategy to reduce misuse, but they have been demonstrated to be modifiable, necessitating the consideration of additional properties to minimize abuse liability and fatalities. We suggest that therapeutics that do not produce reward are most likely to reduce diversion for misuse. Focusing on this approach, we discuss novel interventions that maximize analgesic properties while minimizing reward-promoting effects on the affective state. To provide background information for this section, we have included a table (Table 1) of the clinical use and pharmacological properties of opioids commonly used in the clinic and those that are often abused. This table shows that most opioids used clinically to relieve pain are either full or partial agonists of the mu opioid receptor (MOR) with some activity at other members of the family of opioid receptors.

\section{Biased Agonism of the Mu Opioid Receptor}

Over the years, many opioid compounds have been classified by their efficacy to activate a downstream pathway (such as cAMP), their selectivity for a specific opioid receptor, and ability to desensitize, internalize, and re-sensitize the ligand-bound receptor. More recently, many opioids have been further classified by their ability to induce a specific ligand-receptor conformation to recruit and activate different downstream signaling cascades [reviewed in Ref. (153)]. This bias toward either activation of G-protein-dependent or G-protein-independent, arrestin signaling pathways is known as "biased agonism" (154). This is an exciting discovery with obvious translational significance if specific pathways can indeed be activated to reduce non-analgesic opioid signaling. For MORs and other G-protein coupled receptors, such as the Cannabinoid 1 receptor, agonists biased toward arrestinmediated signaling rather than G-protein-dependent signaling pathways seem to produce greater adverse side effects $(155,156)$. This has led to an emphasis on developing compounds that do not recruit either of the non-visual arrestin isoforms very well. Herkinorin was the first example of a MOR agonist showing that reduction of arrestin-signaling bias is associated with reduced adverse side effects. Using this logic, novel MOR agonists such as TRV130, TRV0109101, and PZM21, have been developed that do not recruit arrestin very well and also induce fewer adverse side effects (156-159). In particular, TRV130 has been shown to be G-protein biased, has a greater or equal analgesic potency to morphine, and induces less tolerance $(160,161)$. However, it is controversial as to whether TRV130 causes less rewarding behaviors, inhibition of gastrointestinal transit, or induction of respiratory depression than morphine $(158,160,161)$. This compound is now in a Phase III clinical trial for parenteral treatment of acute pain (NCT02656875). TRV0109101 is also biased toward G-protein signaling and does not induce hyperalgesia, a common side effect of chronic opioid use (159). PZM21 similarly does not recruit $\beta$-arrestin 2 but is less potent than morphine and appears to induce less constipation, less respiratory depression, and reduced reward-seeking behaviors (158).

Using agonist bias profiles to predict the abuse of the commonly abused semisynthetic and synthetic opioids yields mixed results. For example, morphine shows the same or greater arrestin bias than oxycodone $(162,163)$, yet oxycodone has a greater abuse liability than morphine (136). Fentanyl and its analogs are highly abused yet this class shows no overt bias for either signaling pathway. This suggests that biased agonism alone cannot be used to separate the analgesic from rewarding properties of opioids.

\section{Pharmacokinetics}

The action of opioids in the central nervous system facilitates analgesia mediated at supraspinal sites, such as those in the rostral ventral medulla, but also induces euphoria due to signaling at different central opioid receptor populations mediating reward (164). These central effects of opioids are also the major cause of overdose lethality due to respiratory depression (165), which is mediated by opioid receptors in breath-pattern generating neurons such as those in the pre-Bötzinger's complex of the medulla (166). Limiting the access of opioids to the central nervous system is a beneficial pharmacokinetic manipulation that may bypass these off-target effects while preserving the potential for analgesia mediated by signaling at opioid receptors in the spinal cord or primary nociceptive afferent neurons.

This relationship between the pharmacokinetic profile of opioids and their abuse liability was first described in the 1970s $(167,168)$ and resulted in the use of buprenorphine and methadone as a non-rewarding analgesic or to treat $\operatorname{OUD}(104,167,169)$. It is now well-known that the intrinsic abuse liability of an opioid 
TABLE 1 | Descriptive and clinically relevant information of common opioids including clinical formulations, class of opioid, clinical uses, and cellular targets.

\begin{tabular}{|c|c|c|c|c|}
\hline $\begin{array}{l}\text { Drug [brand or } \\
\text { alternative name(s)] }\end{array}$ & $\begin{array}{l}\text { Common clinical } \\
\text { formulation(s) (USA } \\
\text { unless stated otherwise) }\end{array}$ & Classification; origin & Clinical use & Cellular target \\
\hline $\begin{array}{l}\text { Buprenorphine } \\
\text { (e.g., Suboxone, } \\
\text { Subutex, Buprenex) }\end{array}$ & $\begin{array}{l}\text { Buprenorphine } \\
\text { hydrochloride, buprenorphine } \\
\text { naloxone }(4: 1)\end{array}$ & $\begin{array}{l}\text { Semisynthetic opiate; } \\
\text { thebaine of the opium } \\
\text { poppy (104) }\end{array}$ & $\begin{array}{l}\text { Analgesia and maintenance therapy or } \\
\text { opiate addiction treatment (Step } 3 \text { pain } \\
\text { medication) (104) }\end{array}$ & $\begin{array}{l}\text { Partial MOR agonist, KOR } \\
\text { antagonist, nociceptin receptor } \\
\text { agonist and antagonist }(105,106)\end{array}$ \\
\hline $\begin{array}{l}\text { Fentanyl (e.g., Actiq, } \\
\text { Duragesic, Fentora) }\end{array}$ & Fentanyl citrate & $\begin{array}{l}\text { Synthetic opioid; } \\
\text { N-phenethyl- } \\
\text { piperidone (95) }\end{array}$ & $\begin{array}{l}\text { Chronic and acute pain; administered } \\
\text { orally, IV, transdermal patches (Step } 3 \\
\text { pain medication) }(107,108)\end{array}$ & $\begin{array}{l}\text { Full MOR agonist, weak KOR } \\
\text { agonist (109) }\end{array}$ \\
\hline $\begin{array}{l}\text { Heroin (i.e., } \\
\text { diamorphine) }\end{array}$ & $\begin{array}{l}\text { Diamorphine (UK) (110), } \\
\text { diacetylmorphine (Canada/ } \\
\text { Switzerland) (111) }\end{array}$ & $\begin{array}{l}\text { Opiate; morphine, and } \\
\text { opium poppy (112) }\end{array}$ & $\begin{array}{l}\text { Strong analgesic (Step } 3 \text { pain medication) } \\
(113,114), \text { opiate addiction treatment } \\
\text { (Switzerland, Netherlands, Germany, } \\
\text { England, Denmark) (115) }\end{array}$ & $\begin{array}{l}\text { Partial MOR agonist (116) acts as } \\
\text { prodrug (see active metabolites). }\end{array}$ \\
\hline $\begin{array}{l}\text { Hydrocodone } \\
\text { (i.e., dihydrocodeinone) } \\
\text { (e.g., Zohydro ER, } \\
\text { Vicodin) }\end{array}$ & $\begin{array}{l}\text { Hydrocodone bitartrate, } \\
\text { hydrocodone bitartrate, } \\
\text { and acetaminophen (117) }\end{array}$ & $\begin{array}{l}\text { Semisynthetic opioid } \\
(118,119) \text {; codeine } \\
\text { (from opium poppy) }\end{array}$ & $\begin{array}{l}\text { Chronic pain and opioid maintenance } \\
\text { therapy (117) }\end{array}$ & Full MOR agonist (118) \\
\hline $\begin{array}{l}\text { Hydromorphone } \\
\text { (e.g., Dilaudid) }\end{array}$ & $\begin{array}{l}\text { Hydromorphone } \\
\text { hydrochloride (120) }\end{array}$ & $\begin{array}{l}\text { A semisynthetic opioid; the } \\
\text { hydrogenated ketone of } \\
\text { morphine (121) }\end{array}$ & $\begin{array}{l}\text { Acute and chronic analgesia (Step } 3 \text { pain } \\
\text { medication) (122), } 5-8 \times \text { more potent } \\
\text { than morphine (123) }\end{array}$ & $\begin{array}{l}\text { Full MOR agonist, partial DOR } \\
\text { agonist, and weak KOR agonist } \\
(124,125)\end{array}$ \\
\hline $\begin{array}{l}\text { Methadone } \\
\text { (e.g., Dolophine) }\end{array}$ & $\begin{array}{l}\text { Methadone hydrochloride } \\
{[(R) \text { or racemic mixture }]} \\
(126,127)\end{array}$ & $\begin{array}{l}\text { Synthetic opioid (128); } \\
\text { diphenylacetonitrile (129); } \\
\text { and 1-dimethylamino-2- } \\
\text { chloropropane (130) }\end{array}$ & $\begin{array}{l}\text { Opioid dependence treatment } \\
\text { (detoxification), chronic pain }(131,132)\end{array}$ & $\begin{array}{l}\text { Levo: full MOR agonist (109); } \\
\text { dextro (D) NMDA antagonist (127). }\end{array}$ \\
\hline $\begin{array}{l}\text { Morphine (e.g., } \\
\text { morphine sulfate ER, } \\
\text { Roxanol, MsContin) }\end{array}$ & Morphine sulfate & Opiate; opium poppy (133) & $\begin{array}{l}\text { Acute and chronic pain (Step } 3 \text { pain } \\
\text { medication) (134) }\end{array}$ & $\begin{array}{l}\text { Partial MOR agonist, weak DOR } \\
\text { agonist }(109,135)\end{array}$ \\
\hline $\begin{array}{l}\text { Oxycodone } \\
\text { (e.g., Oxycontin, Norco, } \\
\text { etc.) }\end{array}$ & $\begin{array}{l}\text { Oxycodone hydrochloride, } \\
\text { oxycodone acetaminophen, } \\
\text { and oxycodone aspirin }\end{array}$ & $\begin{array}{l}\text { Semisynthetic opiate; } \\
\text { thebaine of the (136) opium } \\
\text { poppy }(137,138)\end{array}$ & $\begin{array}{l}\text { Acute and chronic pain; may be superior } \\
\text { than morphine for some types of pain } \\
\text { (Step } 3 \text { pain medication) }(139,140)\end{array}$ & $\begin{array}{l}\text { Medium MOR agonist, partial } \\
\text { KOR agonist }(141), \text { and partial } \\
\text { DOR agonist }(137,142)\end{array}$ \\
\hline $\begin{array}{l}\text { Remifentanil } \\
\text { (e.g., Ultiva) }\end{array}$ & $\begin{array}{l}\text { Remifentanil hydrochloride } \\
\text { (always administered IV) }\end{array}$ & $\begin{array}{l}\text { Synthetic opioid (143); } \\
\text { derivative of fentanyl (144) }\end{array}$ & $\begin{array}{l}\text { Acute pain or sedation (50-100x more } \\
\text { potent than morphine) often used for } \\
\text { surgical procedures (145-148) }\end{array}$ & Full MOR agonist (143) \\
\hline $\begin{array}{l}\text { Tramadol } \\
\text { (e.g., Ultram) }\end{array}$ & $\begin{array}{l}\text { Tramadol hydrochloride } \\
\text { [racemic (+/-)], Tramadol } \\
\text { hydrochloride, and } \\
\text { acetaminophen }\end{array}$ & $\begin{array}{l}\text { Synthetic opioid; salicylic } \\
\text { acid with addition } \\
\text { of 3-methoxyphenyl } \\
\text { magnesium halide (149) }\end{array}$ & $\begin{array}{l}\text { Moderate pain (Step } 2 \text { pain medication) } \\
(149,150) \text {. Analgesic potency is } 10 \% \\
\text { that of morphine }(149)\end{array}$ & $\begin{array}{l}(+/-) \text { MOR agonist }(151),(-) \\
\text { monoamine reuptake } \\
\text { inhibitor }(152)\end{array}$ \\
\hline
\end{tabular}

Alternative names refer to either the chemical name (referred to as i.e.) or brand name (referred as e.g.). Pain medication steps of analgesia are derived from World Health Organization classifications.

MOR; mu opioid receptor, DOR; delta opioid receptor, KOR; kappa opioid receptor.

is a product of different pharmacokinetic parameters such as the time to peak plasma concentration, lipid solubility, BBB transport (a combination of passive diffusion and active transport in and out of the brain), and the presence of bioactive metabolites. Abuse liability may also be influenced by availability, with some compounds such as remifentanil being less available than others, such as methadone and heroin. We have outlined these pharmacokinetic properties and the abuse potential of commonly abused opioids and those used clinically (Table 2). This shows that fentanyl is one of the most rapidly bio-available opioids but has the same elimination half-life as morphine. However, it is highly lipid soluble (580x that of morphine) and so more easily crosses the $\mathrm{BBB}$ in both directions, shortening its effective duration of action. Heroin is a prodrug that is quickly transported across the BBB and converted to 6-acetyl-morphine, morphine, and demethylated to hydromorphone (170). Both of these opioids have a high abuse liability, but fentanyl and its derivatives are both more potent and have a longer elimination half-life making the fentanyl family of opioids fatal if taken in unknown or high quantities, as has often been the case (171). In comparison, morphine is hydrophilic, has poor protein binding capacity and its transport across the $\mathrm{BBB}$ is regulated, making it less likely to be abused. Compared with morphine, oxycodone is actively transported across the BBB, has a more rapid onset of effect and several active metabolites that all contribute to its greater abuse profile. At the other end of the spectrum are methadone and buprenorphine with medium-tolow abuse liabilities explained by low BBB permeability and a longer elimination half-life, in addition to differences in receptor selectivity and pharmacological profiles (Tables 1 and 2).

The positive correlation between BBB permeability/transport with abuse liability is the cornerstone of the strategically designed novel mu-opioid agonist, NKTR-181, which is analgesic but has limited abuse liability in humans $(208,209)$. This compound has a poly-ethylene glycol side chain and shows delayed transfer across 
TABLE 2 | The abuse liability, aspects of the pharmacokinetic profile, and bioavailability of select clinical and abused opioid compounds.

\begin{tabular}{|c|c|c|c|c|c|c|}
\hline Drug & Abuse liability & $\begin{array}{l}\text { Onset of effect and } \\
\text { time to peak plasma } \\
\text { concentration (min to h) }\end{array}$ & $\begin{array}{l}\text { Elimination } \\
\text { half-life } \\
\text { (generally } \\
\text { oral/human) }\end{array}$ & Metabolite(s) & Metabolite half-life & $\begin{array}{l}\text { Bioavailability and } \\
\text { blood-brain barrier (BBB) } \\
\text { permeability/transport }\end{array}$ \\
\hline Buprenorphine & $\begin{array}{l}\text { Low in relation } \\
\text { to other opioids } \\
(172,173)\end{array}$ & $\begin{array}{l}\text { Sublingual onset of } \\
0.25-0.75 \mathrm{~h} \text {, peak plasma } \\
\text { concentration at } 2 \mathrm{~h}(174)\end{array}$ & $\begin{array}{l}3-48 \text { h (175), } \\
\text { variable }\end{array}$ & $\begin{array}{l}\text { Buprenorphine- } \\
\text { 3-glucuronide, } \\
\text { norbuprenorphine-3- } \\
\text { glucuronide (106) }\end{array}$ & Unknown (106) & $\begin{array}{l}28-51 \% \text { bioavailability (176), } \\
\text { low BBB permeability (177) }\end{array}$ \\
\hline Fentanyl & $\begin{array}{l}\text { Very high } \\
(178-180)\end{array}$ & $\begin{array}{l}\text { 2-5 min onset of action, } \\
\text { and peak plasma } \\
\text { concentrations of } 20 \text { min } \\
\text { after oral and } 12 \text { min } \\
\text { after intranasal } \\
\text { administration (95) }\end{array}$ & $\begin{array}{l}1.5-7 \mathrm{~h} \\
(181)\end{array}$ & $\begin{array}{l}\text { Norfentanyl; minimal } \\
\text { activity (182) }\end{array}$ & $\mathrm{N} / \mathrm{A}$ & $\begin{array}{l}50-90 \% \text {, highly lipophilic } \\
\text { and high BBB permeability } \\
\text { through passive and active } \\
\text { transport (178, 183). } \\
\text { Transfer half-life of } \\
4.7-6.6 \text { min (95) }\end{array}$ \\
\hline Heroin & Very high (184) & $\begin{array}{l}45 \text { s to onset of effect, } \\
\text { heroin undetectable in } \\
\text { blood and CSF by } 20 \text { min } \\
\text { in rats (185) }\end{array}$ & $\begin{array}{l}3 \min (\mathrm{IV}) \\
(170)\end{array}$ & $\begin{array}{l}\text { 6-Monoacetylmorphine } \\
\text { (6-MAM), morphine, } \\
\text { and morphine's } \\
\text { metabolites (182) }\end{array}$ & $\begin{array}{l}6-M A M<10 \text { min after } \\
\text { BBB crossing (116). } \\
\text { Plasma conversion to } \\
\text { morphine: } 1.5-4.5 \mathrm{~h}, \\
\text { hydromorphone: } 5 \mathrm{~h}, \\
\text { M6G: } 2 \mathrm{~h}, \mathrm{M} 3 \mathrm{G}: 1.5 \mathrm{~h}\end{array}$ & $\begin{array}{l}\text { High (lipophilic) } 60 \% \text { or } \\
\text { greater BBB permeability } \\
(116,186)\end{array}$ \\
\hline Hydrocodone & $\begin{array}{l}\text { High }(136,179, \\
187)\end{array}$ & $\begin{array}{l}10 \text { min to onset of effect } \\
\text { and peak effects within } \\
30-60 \text { min (188) }\end{array}$ & 3-9 h (189) & $\begin{array}{l}\text { Hydromorphone and } \\
\text { norhydrocodone (190). }\end{array}$ & $\begin{array}{l}\text { Hydromorphone: } 5 \\
\text { norhydrocodone: } 8 \text { (191) }\end{array}$ & $\begin{array}{l}25 \% \text { bioavailability; } 50 \% \\
\text { BBB permeability (187) }\end{array}$ \\
\hline Hydromorphone & High (179) & $\begin{array}{l}\text { 5-30 min to onset of } \\
\text { action, } 30 \text { min to peak } \\
\text { effect }(125,189)\end{array}$ & 2-3 h (192) & $\begin{array}{l}\text { Hydromorphone-3- } \\
\text { glucuronide (182) }\end{array}$ & $1.5-3$ h (193) & $\begin{array}{l}55 \% \text { bioavailability (194), } \\
\text { higher BBB permeability } \\
\text { than morphine; transfer } \\
\text { half-life; 18-38 min (191) }\end{array}$ \\
\hline Methadone & Medium (172) & $\begin{array}{l}30 \mathrm{~min} \text { for onset of action, } \\
1-5 \mathrm{~h}(132,185)\end{array}$ & $\begin{array}{l}4-6 \mathrm{~h}(132) \text { or } \\
\text { longer (195) }\end{array}$ & None (196) & $\mathrm{N} / \mathrm{A}$ & $\begin{array}{l}\text { 41-99\% bioavailability (195), } \\
\text { 40\% permeability (186) }\end{array}$ \\
\hline Morphine & High $(136,179)$ & $15-60 \min (125,139)$ & $\begin{array}{l}1.5-4.5 \mathrm{~h} \\
\text { (IV and IM) } \\
(121,137)\end{array}$ & $\begin{array}{l}\text { Active: morphine-6- } \\
\text { glucuronide (M6G) and } \\
\text { hydromorphone. Inactive: } \\
\text { morphine-3-glucuronide } \\
\text { (M3G) (182). }\end{array}$ & $\begin{array}{l}\text { M6G: } 2 \text { h (197); } \\
\text { hydromorphone: } 5 \text { h } \\
\text { (191); M3G: } 1.5 \text { h (198) }\end{array}$ & $\begin{array}{l}30 \% \text { bioavailability, low } \\
\text { BBB permeability; transfer } \\
\text { half-life; } 1.6-4.8 \mathrm{~h}(191)\end{array}$ \\
\hline Oxycodone & $\begin{array}{l}\text { Very high } \\
\text { (greater than } \\
\text { morphine and } \\
\text { hydrocodone) } \\
(136,179)\end{array}$ & $\begin{array}{l}\text { 10-30 min for onset of } \\
\text { action (199), peak plasma } \\
\text { levels occur } \sim 1 \mathrm{~h}(137)\end{array}$ & $\begin{array}{l}2-3 \text { h (199), } \\
3-5 \text { h plasma } \\
\text { after oral } \\
(137)\end{array}$ & $\begin{array}{l}\text { Noroxycodone (low } \\
\text { activity) and oxymorphone } \\
\text { (potency > morphine) } \\
\text { (141), both metabolize } \\
\text { into noroxymorphone } \\
\text { (8-30x morphine's } \\
\text { activity, BBB } \\
\text { impermeable) (141) }\end{array}$ & $\begin{array}{l}\text { Noroxycodone is } \\
\text { converted slowly into } \\
\text { noroxymorphone }(200) \text {, } \\
\text { oxymorphone ( } 7-8 \text { h) } \\
\text { (141), noroxymorphone } \\
\text { significantly longer than } \\
\text { oxycodone (3-5 h but } \\
\text { limited BBB permeability) } \\
\text { (201) }\end{array}$ & $\begin{array}{l}60-90 \% \text { bioavailability } \\
(142) \text {, active transport } \\
\text { across the BBB and can } \\
\text { reach } 3 \times \text { higher levels in the } \\
\text { brain than blood }(140,202)\end{array}$ \\
\hline Remifentanil & $\begin{array}{l}\text { Medium, } \\
\text { possibly due to } \\
\text { low availability } \\
\text { (few cases) } \\
(203,204)\end{array}$ & $1-2 \min (143)$ & $\begin{array}{l}3-4 \min (I V) \\
(143)\end{array}$ & $\begin{array}{l}\text { Remifentanil acid, } \\
\text { relatively inactive (205) }\end{array}$ & Negligible (205) & $\begin{array}{l}50 \% \text { bioavailability and } \\
\text { BBB equilibration half-life } \\
\text { is } 2-5 \text { min ( } 205)\end{array}$ \\
\hline $\begin{array}{l}\text { Tramadol } \\
\text { (e.g., Ultram) }\end{array}$ & $\begin{array}{l}\text { Medium (179, } \\
\text { 206); }\end{array}$ & $2-3$ h $(149,187)$ & $5.1 \mathrm{~h} \mathrm{(149)}$ & $\begin{array}{l}\text { O-desmethyltramadol } \\
\text { (M1), an MOR agonist } \\
\text { (149) }\end{array}$ & $9 \mathrm{~h}(149)$ & Actively transported (207) \\
\hline
\end{tabular}

the BBB (208). It is currently in Phase III clinical trials to treat chronic lower back pain or non-cancer pain (NCT02367820).

\section{Mixed Opioid Agonists}

Another interesting development is the use of ligands that simultaneously bind to and activate multiple receptors to relieve pain. Careful design of these bivalent ligands and their linkers has been shown to increase signaling efficacy of the target receptors, allowing a lower dose of the ligand to be used to achieve the same analgesic effect. Such bitopicity, or action at two sites, was first described for biphalin, a dual enkephalin analog that showed greater analgesic efficacy than enkephalin alone (210). Furthermore, incorporating the pharmacological properties of an opioid that has a reduced abuse liability, i.e., a slow onset of action, a long half-life and low BBB permeability, would result in an effective analgesic that is not rewarding. Several such mixed 
ligands have now been generated that are based on the structure of buprenorphine (211-213), a partial MOR agonist, kappa opioid receptor (KOR)antagonist and nociceptin receptor ligand $(214,215)$ with reduced reward liability $(172,173)$. There are also other bivalent compounds that activate MOR and delta opioid receptors (DOR) (216), MOR and mGluR5 (217), and MOR, DOR and KORs (218).

In summary, we propose that the preclinical examination of novel opioid agonists that are pharmacologically designed to be (1) biased and so able to influence one signaling pathway over another, or (2) show a pharmacological profile that reduces a central duration of action, or (3) are able to signal selectively through mixed receptors, may provide better insight into and predictability of their abuse and lethality profiles. Such novel agonists may also incorporate aspects of each of these designs to obtain the desired clinical outcome. An example of this multifaceted approach is the family of mixed ligands that are based on the structure of buprenorphine, which may target multiple receptors to enhance analgesia but have a buprenorphine-like pharmacological profile of reduced reward and overdose liability. The specificity and effects of these novel pharmaceutical compounds may be further influenced by the use of a positive allosteric modulator for which a conserved site has been found on MORs, DORs, and KORs (219).

\section{TREATING PAIN WITH PERSPECTIVE AND WITH THE PURPOSE OF REDUCING HARM DURING THE OPIOID EPIDEMIC}

Many pain patients have now found themselves physically and psychologically dependent on their opioid prescriptions, as both fail to relieve their pain in the chronic setting but are also now known to be addictive and harmful with long-term use. We have described the etiology of the opioid epidemic from the financial motivation for the over-prescription of these drugs, to the socioeconomic and physical issues that contribute to pain and addiction-prone populations worldwide. Navigating through the devastation caused by the opioid epidemic requires some perspective. While acknowledging that many opioids are harmful and addictive, they are still the most efficacious class of drugs for analgesia. Here, we aim to guide the refinement of

\section{REFERENCES}

1. Defalque RJ, Wright AJ. Scophedal (SEE) was it a fad or a miracle drug? Bull Anesth Hist (2003) 21:12-4. doi:10.1016/S1522-8649(03)50051-8

2. Rappaport B. Overview of the November 13, 2008 ALSDAC Meeting to Discuss NDA 22-324 for Remoxy (Oxycodone Hydrochloride Controlled-Release) Capsules. A. Division of Anesthesia, and Rheumatology Products, Office of Drug Evaluation II, editor (2008).

3. Aquina CT, Marques-Baptista A, Bridgeman P, Merlin MA. OxyContin abuse and overdose. Postgrad Med (2009) 121(2):163-7. doi:10.3810/ pgm.2009.03.1988

4. Van Zee A. The promotion and marketing of oxycontin: commercial triumph, public health tragedy. Am J Public Health (2009) 99(2):221-7. doi:10.2105/ AJPH.2007.131714

5. Ventola CL. Direct-to-consumer pharmaceutical advertising: therapeutic or toxic? P T (2011) 36:669-84. prescription opioid compounds by improving upon the currently available abuse-deterrent formulations. These treatments should maximize analgesic properties by directing ligand bias toward signaling through $\mathrm{G}$-proteins rather than $\beta$-arrestins, delaying or minimizing the BBB entry of drugs, minimizing metabolites with pro-addictive or off-target properties and using mixed agonists to provide more specific clinical effects. These strategies have led to the development of some promising compounds that may provide pain relief while minimizing the likelihood of addiction and misuse. Of course, these pharmaceutical agents should only be used following a comprehensive screening strategy to both exclude patients likely to misuse their medications and to identify those who may respond to alternate, non-opioid-based pain-management strategies.

\section{AUTHOR CONTRIBUTIONS}

This review is the result of a collaboration between basic research scientists and medical professionals. ALS and WW contributed to the conceptualization of the manuscript; edited and wrote the sections of the manuscript concerning the context of the opioid epidemic, pain, biased agonism, and pharmacokinetics. ALS and $\mathrm{KH}$ wrote the sections of the manuscript concerning medical interventions, psychiatric comorbidities to pain and addiction, and the epidemiology. ALS, WW, and JH produced the tables of drug properties. OC and GS contributed to writing and editing of the manuscript. All the authors contributed to the final editing and revision of the paper.

\section{ACKNOWLEDGMENTS}

Thanks are due to Christopher J. Evans for exciting discussion and insight into the opioid epidemic and pharmacological properties of the opioids. Thanks are due to the Shirley and Stefan Hatos Foundation and the National Institute of Drug Abuse (DA005010) for support.

\section{FUNDING}

Funding for this manuscript was provided by NIDA (DA005010) and the Shirley and Stefan Hatos Foundation.

6. Fain KM, Alexander GC. Mind the gap: understanding the effects of pharmaceutical direct-to-consumer advertising. Med Care (2014) 52: 291-3.

7. Sackler Family [Online]. Forbes (2016). Available from: https://www.forbes. com/profile/sackler/ (Accessed: October 12, 2017)

8. Eban K. OxyContin: Purdue Pharma's painful medicine. Fortune (2011). Available from: https://fortune.com/2011/11/09/oxycontin-purdue-pharmaspainful-medicine/

9. Drug Overdose Deaths in the United States Continue to Increase in 2015 [Online]. (2016). Available from: https://www.cdc.gov/drugoverdose/epidemic/ (Accessed: October 30, 2017).

10. Jones JP. United States of America v. The Purdue Frederick Company, INC., et al. In the United States District Court for the Western District of Virginia Abingdon Division (2007). 07CR00029.

11. Whalen J. Purdue Pharma to Stop Promoting OxyContin to U.S. Doctors. In: The Wall Street Journal (2018). New York: The Wall Street Journal. Available from: 
https://www.wsj.com/articles/purdue-pharma-to-stop-promoting-oxycontinto-u-s-doctors-1518307565

12. Sees KL, Di Marino ME, Ruediger NK, Sweeney CT, Shiffman S. Non-medical use of oxycontin tablets in the United States. J Pain Palliat Care Pharmacother (2005) 19:13-23. doi:10.1080/J354v19n02_04

13. The DAWN Report: Highlights of the 2011 Drug Abuse Warning Network (DAWN) Findings on Drug-Related Emergency Department Visits. Rockville, MD: Substance Abuse and Mental Health Services Administration (2013).

14. Zielinska M, Ben Haddou T, Cami-Kobeci G, Salaga M, Jarmuz A, Padysz M, et al. Anti-inflammatory effect of dual nociceptin and opioid receptor agonist, BU08070, in experimental colitis in mice. Eur J Pharmacol (2015) 765:582-90. doi:10.1016/j.ejphar.2015.09.021

15. Rudd RA, Seth P, David F, Scholl L. Increases in drug and opioid-involved overdose deaths - United States, 2010-2015. MMWR Morb Mortal Wkly Rep (2016) 65:1445-52. doi:10.15585/mmwr.mm655051e1

16. Helmerhorst GT, Teunis T, Janssen SJ, Ring D. An epidemic of the use, misuse and overdose of opioids and deaths due to overdose, in the United States and Canada: is Europe next? Bone Joint J (2017) 99-B:856-64. doi:10.1302/0301620X.99B7.BJJ-2016-1350.R1

17. Martins SS, Ghandour LA. Nonmedical use of prescription drugs in adolescents and young adults: not just a western phenomenon. World Psychiatry (2017) 16:102-4. doi:10.1002/wps.20350

18. Pilgrim JL, Yafistham SP, Gaya S, Saar E, Drummer OH. An update on oxycodone: lessons for death investigators in Australia. Forensic Sci Med Pathol (2015) 11:3-12. doi:10.1007/s12024-014-9624-x

19. Hakkinen M, Launiainen T, Vuori E, Ojanpera I. Comparison of fatal poisonings by prescription opioids. Forensic Sci Int (2012) 222:327-31. doi:10.1016/j. forsciint.2012.07.011

20. Giraudon I, Lowitz K, Dargan PI, Wood DM, Dart RC. Prescription opioid abuse in the UK. Br J Clin Pharmacol (2013) 76:823-4. doi:10.1111/bcp.12133

21. Manchikanti L, Singh A. Therapeutic opioids: a ten-year perspective on the complexities and complications of the escalating use, abuse, and nonmedical use of opioids. Pain Physician (2008) 11:S63-88.

22. Hall AJ, Logan JE, Toblin RL, Kaplan JA, Kraner JC, Bixler D, et al. Patterns of abuse among unintentional pharmaceutical overdose fatalities. JAMA (2008) 300:2613-20. doi:10.1001/jama.2008.802

23. Paulozzi LJ, Mack KA, Hockenberry JM. Variation among states in prescribing of opioid pain relievers and benzodiazepines - United States, 2012.J Safety Res (2014) 51:125-9. doi:10.1016/j.jsr.2014.09.001

24. Paulozzi LJ, Strickler GK, Kreiner PW, Koris CM; Centers for Disease Conrol and Prevention. Controlled substance prescribing patterns - prescription behavior surveillance system, eight states, 2013. MMWR Surveill Summ (2015) 64:1-14. doi:10.15585/mmwr.ss6409a1

25. Woolley SM, Meacham SL, Balmert LC, Talbott EO, Buchanich JM. Comparison of mortality disparities in central appalachian coal- and non-coalmining counties. J Occup Environ Med (2015) 57:687-94. doi:10.1097/JOM. 0000000000000435

26. Becker WC, Sullivan LE, Tetrault JM, Desai RA, Fiellin DA. Non-medical use, abuse and dependence on prescription opioids among U.S. adults: psychiatric, medical and substance use correlates. Drug Alcohol Depend (2008) 94:38-47. doi:10.1016/j.drugalcdep.2007.09.018

27. Case A, Deaton A. Rising morbidity and mortality in midlife among white non-Hispanic Americans in the 21st century. Proc Natl Acad Sci U S A (2015) 112:15078-83. doi:10.1073/pnas.1518393112

28. Wilkerson RG, Kim HK, Windsor TA, Mareiniss DP. The opioid epidemic in the United States. Emerg Med Clin North Am (2016) 34:e1-23. doi:10.1016/j. emc.2015.11.002

29. Hedegaard HW, Warner M, Minio AM. Drug Overdose Deaths in the United States, 1999-2015. Hyattsville, MD: N.C.F.H. Statistics (2017).

30. Case A, Deaton A. Mortality and morbidity in the 21st century. Brookings Papers on Economic Activity. (2017).

31. Shern DL, Blanch AK, Steverman SM. Toxic stress, behavioral health, and the next major era in public health. Am J Orthopsychiatry (2016) 86:109-23. doi:10.1037/ort0000120

32. Modrek S, Hamad R, Cullen MR. Psychological well-being during the great recession: changes in mental health care utilization in an occupational cohort. Am J Public Health (2015) 105:304-10. doi:10.2105/AJPH.2014.302219

33. Hollingsworth A, Ruhm CJ, Simon K. Macroeconomic conditions and opioid abuse. J Health Econ (2017) 56:222-33. doi:10.1016/j.jhealeco.2017.07.009
34. Nagelhout GE, Hummel K, De Goeij MCM, De Vries H, Kaner E, Lemmens P. How economic recessions and unemployment affect illegal drug use: a systematic realist literature review. Int J Drug Policy (2017) 44:69-83. doi:10.1016/j. drugpo.2017.03.013

35. Friedman DP. Perspectives on the medical use of drugs of abuse. J Pain Symptom Manage (1990) 5:S2-5.

36. Tucker C. Acute pain and substance abuse in surgical patients. J Neurosci Nurs (1990) 22:339-49. doi:10.1097/01376517-199012000-00003

37. Tunca M, Yelken J. Undertreatment of cancer pain. Lancet (1991) 337:1294. doi:10.1016/0140-6736(91)92968-8

38. Zinberg NE. Heroin use in Vietnam and the United States. A contrast and a critique. Arch Gen Psychiatry (1972) 26:486-8. doi:10.1001/archpsyc.1972. 01750230096019

39. Manchikanti L, Helm S II, Fellows B, Janata JW, Pampati V, Grider JS, et al. Opioid epidemic in the United States. Pain Physician (2012) 15:ES9-38.

40. Ping A, Xi J, Prasad BM, Wang MH, Kruzich PJ. Contributions of nucleus accumbens core and shell GluR1 containing AMPA receptors in AMPA- and cocaine-primed reinstatement of cocaine-seeking behavior. Brain Res (2008) 1215:173-82. doi:10.1016/j.brainres.2008.03.088

41. Kenan K, Mack K, Paulozzi L. Trends in prescriptions for oxycodone and other commonly used opioids in the United States, 2000-2010. Open Med (2012) 6:e41-7.

42. Cummins S, Leischow S, Bailey L, Bush T, Wassum K, Copeland L, et al. Knowledge and beliefs about electronic cigarettes among quitline cessation staff. Addict Behav (2016) 60:78-83. doi:10.1016/j.addbeh.2016.03.031

43. Daubresse M, Chang HY, Yu Y, Viswanathan S, Shah ND, Stafford RS, et al. Ambulatory diagnosis and treatment of nonmalignant pain in the United States, 2000-2010. Med Care (2013) 51:870-8. doi:10.1097/MLR.0b013e3182a95d86

44. Chang HY, Daubresse M, Kruszewski SP, Alexander GC. Prevalence and treatment of pain in EDs in the United States, 2000 to 2010. Am J Emerg Med (2014) 32:421-31. doi:10.1016/j.ajem.2014.01.015

45. Committee on Advancing Pain Research, Care, And Education. Summary. Relieving Pain in America: A Blueprint for Transforming Prevention, Care, Education, and Research (2011). Washington, DC: National Academies Press (2011).

46. Volkow ND. America's Addiction to Opioids: Heroin and Prescription Drug Abuse. N.I.o.D. Abuse, editors. Washington DC: NIDA (2014).

47. Porter J, Jick H. Addiction rare in patients treated with narcotics. N Engl J Med (1980) 302:123. doi:10.1056/NEJM198001103020221

48. Perry S, Heidrich G. Management of pain during debridement: a survey of U.S. burn units. Pain (1982) 13:267-80. doi:10.1016/0304-3959(82) 90016-1

49. Portenoy RK, Foley KM. Chronic use of opioid analgesics in non-malignant pain: report of 38 cases. Pain (1986) 25:171-86. doi:10.1016/0304-3959 (86)90091-6

50. Leung PTM, Macdonald EM, Stanbrook MB, Dhalla IA, Juurlink DN. A 1980 letter on the risk of opioid addiction. N Engl J Med (2017) 376:2194-5. doi:10.1056/NEJMc1700150

51. Brezing C, Bisaga A. Opioid Use Disorder: Update on Diagnosis and Treatment [Online]. Psychiatric Times Editorial (2015). Available from: http://www. psychiatrictimes.com/special-reports/opioid-use-disorder-update-diagnosisand-treatment (Accessed: August 11, 2017).

52. Fishbain DA, Rosomoff HL, Rosomoff RS. Drug abuse, dependence, and addiction in chronic pain patients. Clin J Pain (1992) 8:77-85. doi:10.1097/ 00002508-199206000-00003

53. Hoffmann NG, Olofsson O, Salen B, Wickstrom L. Prevalence of abuse and dependency in chronic pain patients. Int J Addict (1995) 30:919-27. doi:10.3109/ 10826089509055820

54. Chabal C, Erjavec MK, Jacobson L, Mariano A, Chaney E. Prescription opiate abuse in chronic pain patients: clinical criteria, incidence, and predictors. Clin J Pain (1997) 13:150-5. doi:10.1097/00002508-199706000-00009

55. Kouyanou K, Pither CE, Wessely S. Medication misuse, abuse and dependence in chronic pain patients. J Psychosom Res (1997) 43:497-504. doi:10.1016/ S0022-3999(97)00171-2

56. Reid MC, Engles-Horton LL, Weber MB, Kerns RD, Rogers EL, O'Connor PG. Use of opioid medications for chronic noncancer pain syndromes in primary care. J Gen Intern Med (2002) 17:173-9. doi:10.1046/j.1525-1497.2002.10435.x

57. Katz NP, Sherburne S, Beach M, Rose RJ, Vielguth J, Bradley J, et al. Behavioral monitoring and urine toxicology testing in patients receiving long-term 
opioid therapy. Anesth Analg (2003) 97:1097-102. doi:10.1213/01.ANE. 0000080159.83342.B5

58. Edlund MJ, Sullivan M, Steffick D, Harris KM, Wells KB. Do users of regularly prescribed opioids have higher rates of substance use problems than nonusers? Pain Med (2007) 8:647-56. doi:10.1111/j.1526-4637.2006.00200.x

59. Hojsted J, Sjogren P. Addiction to opioids in chronic pain patients: a literature review. Eur J Pain (2007) 11:490-518. doi:10.1016/j.ejpain.2006.08.004

60. Michna E, Jamison RN, Pham LD, Ross EL, Janfaza D, Nedeljkovic SS, et al. Urine toxicology screening among chronic pain patients on opioid therapy: frequency and predictability of abnormal findings. Clin J Pain (2007) 23:173-9. doi:10.1097/AJP.0b013e31802b4f95

61. Fishbain DA, Cole B, Lewis J, Rosomoff HL, Rosomoff RS. What percentage of chronic nonmalignant pain patients exposed to chronic opioid analgesic therapy develop abuse/addiction and/or aberrant drug-related behaviors? A structured evidence-based review. Pain Med (2008) 9:444-59. doi:10.1111/j. 1526-4637.2007.00370.x

62. Vowles KE, Mcentee ML, Julnes PS, Frohe T, Ney JP, Van Der Goes DN. Rates of opioid misuse, abuse, and addiction in chronic pain: a systematic review and data synthesis. Pain (2015) 156:569-76. doi:10.1097/01.j.pain. 0000460357.01998.f1

63. Feingold D, Goor-Aryeh I, Bril S, Delayahu Y, Lev-Ran S. Problematic use of prescription opioids and medicinal cannabis among patients suffering from chronic pain. Pain Med (2017) 18(2):294-306. doi:10.1093/pm/pnw134

64. Berrocoso E, Sanchez-Blazquez P, Garzon J, Mico JA. Opiates as antidepressants. Curr Pharm Des (2009) 15:1612-22. doi:10.2174/ 138161209788168100

65. Yalcin I, Barrot M. The anxiodepressive comorbidity in chronic pain. Curr Opin Anaesthesiol (2014) 27:520-7. doi:10.1097/ACO.0000000000000116

66. Cicero TJ, Ellis MS. Abuse-deterrent formulations and the prescription opioid abuse epidemic in the United States: lessons learned from oxycontin. JAMA Psychiatry (2015) 72:424-30. doi:10.1001/jamapsychiatry.2014.3043

67. Li JX. Pain and depression comorbidity: a preclinical perspective. Behav Brain Res (2015) 276:92-8. doi:10.1016/j.bbr.2014.04.042

68. Scherrer JF, Salas J, Copeland LA, Stock EM, Schneider FD, Sullivan M, et al. Increased risk of depression recurrence after initiation of prescription opioids in noncancer pain patients. J Pain (2016) 17:473-82. doi:10.1016/j. jpain.2015.12.012

69. Wasan AD, Michna E, Edwards RR, Katz JN, Nedeljkovic SS, Dolman AJ, et al. Psychiatric comorbidity is associated prospectively with diminished opioid analgesia and increased opioid misuse in patients with chronic low back pain. Anesthesiology (2015) 123:861-72. doi:10.1097/ALN.0000000000000768

70. Arteta J, Cobos B, Hu Y, Jordan K, Howard K. Evaluation of how depression and anxiety mediate the relationship between pain catastrophizing and prescription opioid misuse in a chronic pain population. Pain Med (2016) 17:295-303.

71. Edwards RR, Dolman AJ, Michna E, Katz JN, Nedeljkovic SS, Janfaza D, et al. Changes in pain sensitivity and pain modulation during oral opioid treatment: the impact of negative affect. Pain Med (2016) 17(10):1882-91. doi:10.1093/ $\mathrm{pm} / \mathrm{pnw} 010$

72. Chow MJ, Ambre JJ, Ruo TI, Atkinson AJ Jr, Bowsher DJ, Fischman MW. Kinetics of cocaine distribution, elimination, and chronotropic effects. Clin Pharmacol Ther (1985) 38:318-24. doi:10.1038/clpt.1985.179

73. De Pinto M, Cahana A. Medical management of acute pain in patients with chronic pain. Expert Rev Neurother (2012) 12:1325-38. doi:10.1586/ern.12.123

74. Blanco C, Wall MM, Okuda M, Wang S, Iza M, Olfson M. Pain as a predictor of opioid use disorder in a nationally representative sample. Am J Psychiatry (2016) 173(12):1189-95. doi:10.1176/appi.ajp.2016.15091179

75. Solomon RL, Corbit JD. An opponent-process theory of motivation. I. Temporal dynamics of affect. Psychol Rev (1974) 81:119-45.

76. Zhou Y, Leri F. Neuroscience of opiates for addiction medicine: from stressresponsive systems to behavior. Prog Brain Res (2016) 223:237-51. doi:10.1016/ bs.pbr.2015.09.001

77. Gerra G, Zaimovic A, Moi G, Bussandri M, Bubici C, Mossini M, et al. Aggressive responding in abstinent heroin addicts: neuroendocrine and personality correlates. Prog Neuropsychopharmacol Biol Psychiatry (2004) 28:129-39. doi:10.1016/j.pnpbp.2003.09.029

78. Kakko J, Von Wachenfeldt J, Svanborg KD, Lidstrom J, Barr CS, Heilig M. Mood and neuroendocrine response to a chemical stressor, metyrapone, in buprenorphine-maintained heroin dependence. Biol Psychiatry (2008) 63:172-7. doi:10.1016/j.biopsych.2007.05.001
79. Robinson TE, Berridge KC. The neural basis of drug craving: an incentivesensitization theory of addiction. Brain Res Brain Res Rev (1993) 18:247-91. doi:10.1016/0165-0173(93)90013-P

80. Kalivas PW, Volkow ND. The neural basis of addiction: a pathology of motivation and choice. Am J Psychiatry (2005) 162:1403-13. doi:10.1176/appi. ajp.162.8.1403

81. Koob GF, Volkow ND. Neurobiology of addiction: a neurocircuitry analysis. Lancet Psychiatry (2016) 3:760-73. doi:10.1016/S2215-0366(16)00104-8

82. Volkow ND, Koob GF, Mclellan AT. Neurobiologic advances from the brain disease model of addiction. N Engl J Med (2016) 374:363-71. doi:10.1056/ NEJMra1511480

83. Koob GF, Le Moal M. Drug addiction, dysregulation of reward, and allostasis. Neuropsychopharmacology (2001) 24:97-129. doi:10.1016/S0893133X(00)00195-0

84. Garland EL, Bryan CJ, Nakamura Y, Froeliger B, Howard MO. Deficits in autonomic indices of emotion regulation and reward processing associated with prescription opioid use and misuse. Psychopharmacology (Berl) (2017) 234:621-9. doi:10.1007/s00213-016-4494-4

85. Huhn AS, Meyer RE, Harris JD, Ayaz H, Deneke E, Stankoski DM, et al. Evidence of anhedonia and differential reward processing in prefrontal cortex among post-withdrawal patients with prescription opiate dependence. Brain Res Bull (2016) 123:102-9. doi:10.1016/j.brainresbull.2015.12.004

86. Leitl MD, Negus SS. Pharmacological modulation of neuropathic painrelated depression of behavior: effects of morphine, ketoprofen, bupropion and [INCREMENT]9-tetrahydrocannabinol on formalin-induced depression of intracranial self-stimulation in rats. Behav Pharmacol (2016) 27:364-76. doi:10.1097/FBP.0000000000000207

87. Finan PH, Remeniuk B, Dunn KE. The risk for problematic opioid use in chronic pain: what can we learn from studies of pain and reward? Prog Neuropsychopharmacol Biol Psychiatry (2017). doi:10.1016/j.pnpbp.2017. 07.029

88. Elvemo NA, Landro NI, Borchgrevink PC, Haberg AK. Reward responsiveness in patients with chronic pain. Eur J Pain (2015) 19:1537-43. doi:10.1002/ ejp. 687

89. Woller SA, Moreno GL, Hart N, Wellman PJ, Grau JW, Hook MA. Analgesia or addiction? Implications for morphine use after spinal cord injury. J Neurotrauma (2012) 29:1650-62. doi:10.1089/neu.2011.2100

90. Hipolito L, Wilson-Poe A, Campos-Jurado Y, Zhong E, Gonzalez-Romero J, Virag L, et al. Inflammatory pain promotes increased opioid selfadministration: role of dysregulated ventral tegmental area mu opioid receptors. J Neurosci (2015) 35:12217-31. doi:10.1523/JNEUROSCI.1053-15.2015

91. Kaufling J, Aston-Jones G. Persistent adaptations in afferents to ventral tegmental dopamine neurons after opiate withdrawal. J Neurosci (2015) 35:10290-303. doi:10.1523/JNEUROSCI.0715-15.2015

92. Park PE, Schlosburg JE, Vendruscolo LF, Schulteis G, Edwards S, Koob GF. Chronic CRF1 receptor blockade reduces heroin intake escalation and dependence-induced hyperalgesia. Addict Biol (2015) 20:275-84. doi:10.1111/ adb. 12120

93. Wade CL, Vendruscolo LF, Schlosburg JE, Hernandez DO, Koob GF. Compulsive-like responding for opioid analgesics in rats with extended access. Neuropsychopharmacology (2015) 40:421-8. doi:10.1038/npp.2014.188

94. Wade CL, Krumenacher P, Kitto KF, Peterson CD, Wilcox GL, Fairbanks CA. Effect of chronic pain on fentanyl self-administration in mice. PLoS One (2013) 8:e79239. doi:10.1371/journal.pone.0079239

95. Lotsch J, Walter C, Parnham MJ, Oertel BG, Geisslinger G. Pharmacokinetics of non-intravenous formulations of fentanyl. Clin Pharmacokinet (2013) 52:23-36. doi:10.1007/s40262-012-0016-7

96. Hou YY, Cai YQ, Pan ZZ. Persistent pain maintains morphine-seeking behavior after morphine withdrawal through reduced MeCP2 repression of GluA1 in rat central amygdala. J Neurosci (2015) 35:3689-700. doi:10.1523/ JNEUROSCI.3453-14.2015

97. Worley MJ, Heinzerling KG, Shoptaw S, Ling W. Volatility and change in chronic pain severity predict outcomes of treatment for prescription opioid addiction. Addiction (2017) 112:1202-9. doi:10.1111/add.13782

98. Sharma A, Kelly SM, Mitchell SG, Gryczynski J, O'Grady KE, Schwartz RP. Update on barriers to pharmacotherapy for opioid use disorders. Curr Psychiatry Rep (2017) 19:35. doi:10.1007/s11920-017-0783-9

99. Weiss RD, Potter JS, Fiellin DA, Byrne M, Connery HS, Dickinson W, et al. Adjunctive counseling during brief and extended buprenorphine-naloxone 
treatment for prescription opioid dependence: a 2-phase randomized controlled trial. Arch Gen Psychiatry (2011) 68:1238-46. doi:10.1001/archgenpsychiatry. 2011.121

100. Worley MJ, Heinzerling KG, Shoptaw S, Ling W. Pain volatility and prescription opioid addiction treatment outcomes in patients with chronic pain. Exp Clin Psychopharmacol (2015) 23:428-35. doi:10.1037/pha0000039

101. Griffin ML, Mcdermott KA, Mchugh RK, Fitzmaurice GM, Jamison RN, Weiss RD. Longitudinal association between pain severity and subsequent opioid use in prescription opioid dependent patients with chronic pain. Drug Alcohol Depend (2016) 163:216-21. doi:10.1016/j.drugalcdep. 2016.04.023

102. Seltzman HH, Shiner C, Hirt EE, Gilliam AF, Thomas BF, Maitra R, et al. Peripherally selective cannabinoid 1 receptor (cblr) agonists for the treatment of neuropathic pain. J Med Chem (2016) 59:7525-43. doi:10.1021/acs. jmedchem.6b00516

103. Kaiser RS, Mooreville M, Kannan K. Psychological interventions for the management of chronic pain: a review of current evidence. Curr Pain Headache Rep (2015) 19:43. doi:10.1007/s11916-015-0517-9

104. Heel RC, Brogden RN, Speight TM, Avery GS. Buprenorphine: a review of its pharmacological properties and therapeutic efficacy. Drugs (1979) 17:81-110. doi:10.2165/00003495-197917020-00001

105. Lutfy K, Cowan A. Buprenorphine: a unique drug with complex pharmacology. Curr Neuropharmacol (2004) 2:395-402. doi:10.2174/1570159043359477

106. Brown SM, Holtzman M, Kim T, Kharasch ED. Buprenorphine metabolites, buprenorphine-3-glucuronide and norbuprenorphine-3-glucuronide, are biologically active. Anesthesiology (2011) 115:1251-60. doi:10.1097/ALN. ob013e318238fea0

107. Lane ME. The transdermal delivery of fentanyl. Eur J Pharm Biopharm (2013) 84:449-55. doi:10.1016/j.ejpb.2013.01.018

108. Smith HS, Colson J, Sehgal N. An update of evaluation of intravenous sedation on diagnostic spinal injection procedures. Pain Physician (2013) 16:SE217-28.

109. Raynor K, Kong H, Chen Y, Yasuda K, Yu L, Bell GI, et al. Pharmacological characterization of the cloned kappa-, delta-, and mu-opioid receptors. Mol Pharmacol (1994) 45:330-4.

110. Bell J. Pharmacological maintenance treatments of opiate addiction. Br J Clin Pharmacol (2014) 77:253-63. doi:10.1111/bcp.12051

111. Oviedo-Joekes E, Guh D, Brissette S, Marchand K, Macdonald S, Lock K, et al. Hydromorphone compared with diacetylmorphine for long-term opioid dependence: a randomized clinical trial. JAMA Psychiatry (2016) 73:447-55. doi:10.1001/jamapsychiatry.2016.0109

112. Oye KA, Lawson JC, Bubela T. Drugs: regulate 'home-brew' opiates. Nature (2015) 521:281-3. doi:10.1038/521281a

113. Opioids in Palliative Care: Safe and Effective Prescribing of Strong Opioids for Pain in Palliative Care of Adults. Cardiff UK: National Collaborating Centre for Cancer (2012).

114. Friedrichsdorf SJ, Postier A. Management of breakthrough pain in children with cancer. J Pain Res (2014) 7:117-23. doi:10.2147/JPR.S58862

115. Uchtenhagen AA. Heroin maintenance treatment: from idea to research to practice. Drug Alcohol Rev (2011) 30:130-7. doi:10.1111/j.1465-3362. 2010.00266.x

116. Gottas A, Oiestad EL, Boix F, Vindenes V, Ripel A, Thaulow CH, et al. Levels of heroin and its metabolites in blood and brain extracellular fluid after i.v. heroin administration to freely moving rats. Br J Pharmacol (2013) 170:546-56. doi:10.1111/bph.12305

117. Vadivelu N, Schermer E, Kodumudi G, Berger JM. The clinical applications of extended-release abuse-deterrent opioids. CNS Drugs (2016) 30:637-46. doi:10.1007/s40263-016-0357-0

118. Vallejo R, Barkin RL, Wang VC. Pharmacology of opioids in the treatment of chronic pain syndromes. Pain Physician (2011) 14:E343-60.

119. Harris SC, Cipriano A, Colucci SV, Kapil RP, Geoffroy P, Hopyan T, et al. Intranasal abuse potential, pharmacokinetics, and safety of once-daily, single-entity, extended-release hydrocodone (HYD) in recreational opioid users. Pain Med (2016) 17:820-31. doi:10.1093/pm/pnv004

120. Dilaudid ${ }^{\circledR}$ Oral Liquid and Dilaudid ${ }^{\circledR}$ Tablets [Online]. (2007). Available from: https://www.accessdata.fda.gov/drugsatfda_docs/label/2007/019892s015lbl.pdf (Accessed: August 15, 2017).

121. MORPHINE. Toxinet: Toxicology Data Network [Online]. NIH Division of Specialized Information Services: US National Library of Medicine (2016).
Available from: https://toxnet.nlm.nih.gov/cgi-bin/sis/search/a?dbs+hsdb:@ term+@DOCNO+2134 (Accessed: August 15, 2017).

122. Bao YJ, Hou W, Kong XY, Yang L, Xia J, Hua BJ, et al. Hydromorphone for cancer pain. Cochrane Database Syst Rev (2016) 10:CD011108.

123. Sarhill N, Walsh D, Nelson KA. Hydromorphone: pharmacology and clinical applications in cancer patients. Support Care Cancer (2001) 9:84-96. doi:10.1007/s005200000183

124. Ananthan S, Khare NK, Saini SK, Seitz LE, Bartlett JL, Davis P, et al. Identification of opioid ligands possessing mixed micro agonist/delta antagonist activity among pyridomorphinans derived from naloxone, oxymorphone, and hydromorphone [correction of hydropmorphone]. J Med Chem (2004) 47:1400-12. doi:10.1021/jm0400597

125. Trescot AM, Datta S, Lee M, Hansen H. Opioid pharmacology. Pain Physician (2008) 11:S133-53.

126. Schwertschlag U, Schrier RW, Wilson P. Beneficial effects of calcium channel blockers and calmodulin binding drugs on in vitro renal cell anoxia. J Pharmacol Exp Ther (1986) 238:119-24.

127. Inturrisi CE. Pharmacology of methadone and its isomers. Minerva Anestesiol (2005) 71:435-7.

128. Pathan H, Williams J. Basic opioid pharmacology: an update. Br J Pain (2012) 6:11-6. doi:10.1177/2049463712438493

129. Cardos SF, Florman AL, Simberkoff MS, Lanier L. Serratia marcescens: use of detailed characterization of strains to evaluate an increase of isolates in an intensive care unit. Am J Med Sci (1973) 266:447-52. doi:10.1097/00000441197312000-00006

130. Casy AF, Parfitt RT. Opioid Analgesics [Online]. 1 ed. US: Springer (1986).

131. Ternes JW, O'Brien CP. The opioids: abuse liability and treatments for dependence. Adv Alcohol Subst Abuse (1990) 9:27-45. doi:10.1300/ J251v09n01_03

132. Brown R, Kraus C, Fleming M, Reddy S. Methadone: applied pharmacology and use as adjunctive treatment in chronic pain. Postgrad Med J (2004) 80:654-9. doi:10.1136/pgmj.2004.022988

133. Onoyovwe A, Hagel JM, Chen X, Khan MF, Schriemer DC, Facchini PJ. Morphine biosynthesis in opium poppy involves two cell types: sieve elements and laticifers. Plant Cell (2013) 25:4110-22. doi:10.1105/tpc.113.115113

134. Gupta M, Msambichaka L, Ballas SK, Gupta K. Morphine for the treatment of pain in sickle cell disease. ScientificWorldJournal (2015) 2015:540154. doi:10.1155/2015/540154

135. Yekkirala AS, Kalyuzhny AE, Portoghese PS. Standard opioid agonists activate heteromeric opioid receptors: evidence for morphine and [d-Ala(2)MePhe(4)-Glyol(5)]enkephalin as selective mu-delta agonists. ACS Chem Neurosci (2010) 1:146-54. doi:10.1021/cn9000236

136. Wightman R, Perrone J, Portelli I, Nelson L. Likeability and abuse liability of commonly prescribed opioids. J Med Toxicol (2012) 8:335-40. doi:10.1007/ s13181-012-0263-x

137. Ordonez Gallego A, Gonzalez Baron M, Espinosa Arranz E. Oxycodone: a pharmacological and clinical review. Clin Transl Oncol (2007) 9:298-307. doi:10.1007/s12094-007-0057-9

138. Kimishima A, Umihara H, Mizoguchi A, Yokoshima S, Fukuyama T. Synthesis of (-)-oxycodone. Org Lett (2014) 16:6244-7. doi:10.1021/ol503175n

139. Lugo RA, Kern SE. Clinical pharmacokinetics of morphine. J Pain Palliat Care Pharmacother (2002) 16:5-18. doi:10.1080/J354v16n04_02

140. Okura T, Hattori A, Takano Y, Sato T, Hammarlund-Udenaes M, Terasaki T, et al. Involvement of the pyrilamine transporter, a putative organic cation transporter, in blood-brain barrier transport of oxycodone. Drug Metab Dispos (2008) 36:2005-13. doi:10.1124/dmd.108.022087

141. Prommer E. Oxymorphone: a review. Support Care Cancer (2006) 14:109-15. doi:10.1007/s00520-005-0917-1

142. Olkkola KT, Kontinen VK, Saari TI, Kalso EA. Does the pharmacology of oxycodone justify its increasing use as an analgesic? Trends Pharmacol Sci (2013) 34:206-14. doi:10.1016/j.tips.2013.02.001

143. Michelsen LG, Hug CC Jr. The pharmacokinetics of remifentanil. JClin Anesth (1996) 8:679-82. doi:10.1016/S0952-8180(96)00179-1

144. Feldman PL, Chorghade MS. Discovery and development of the ultrashortacting analgesic remifentanil. In: Chorghade MS, editor. Drug Discovery and Development. Wiley online library (2006). p. 339-42.

145. Gesztesi Z, Mootz BL, White PF. The use of a remifentanil infusion for hemodynamic control during intracranial surgery. Anesth Analg (1999) 89:1282-7. doi:10.1097/00000539-199911000-00038 
146. Grottke O, Dietrich PJ, Wiegels S, Wappler F. Intraoperative wake-up test and postoperative emergence in patients undergoing spinal surgery: a comparison of intravenous and inhaled anesthetic techniques using short-acting anesthetics. Anesth Analg (2004) 99:1521-7. doi:10.1213/01.ANE.0000134684. 25322.26

147. Knapik M, Knapik P, Nadziakiewicz P, Misiolek H, Saucha W, Walaszczyk M, et al. Comparison of remifentanil or fentanyl administration during isoflurane anesthesia for coronary artery bypass surgery. Med Sci Monit (2006) 12:I33-8.

148. De Baerdemaeker LE, Jacobs S, Pattyn P, Mortier EP, Struys MM. Influence of intraoperative opioid on postoperative pain and pulmonary function after laparoscopic gastric banding: remifentanil TCI vs sufentanil TCI in morbid obesity. Br J Anaesth (2007) 99:404-11. doi:10.1093/bja/aem164

149. Dayer P, Desmeules J, Collart L. [Pharmacology of tramadol]. Drugs (1997) 53(Suppl 2):18-24. doi:10.2165/00003495-199700532-00006

150. Grond S, Sablotzki A. Clinical pharmacology of tramadol. Clin Pharmacokinet (2004) 43:879-923. doi:10.2165/00003088-200443130-00004

151. Hennies HH, Friderichs E, Schneider J. Receptor binding, analgesic and antitussive potency of tramadol and other selected opioids. Arzneimittelforschung (1988) 38:877-80.

152. Leppert W. Tramadol as an analgesic for mild to moderate cancer pain. Pharmacol Rep (2009) 61:978-92. doi:10.1016/S1734-1140(09)70159-8

153. Williams JT, Ingram SL, Henderson G, Chavkin C, Von Zastrow M, Schulz S, et al. Regulation of mu-opioid receptors: desensitization, phosphorylation, internalization, and tolerance. Pharmacol Rev (2013) 65:223-54. doi:10.1124/ pr.112.005942

154. Shukla AK, Violin JD, Whalen EJ, Gesty-Palmer D, Shenoy SK, Lefkowitz RJ. Distinct conformational changes in beta-arrestin report biased agonism at seven-transmembrane receptors. Proc Natl Acad Sci U S A (2008) 105: 9988-93. doi:10.1073/pnas.0804246105

155. Priestley R, Glass M, Kendall D. Functional selectivity at cannabinoid receptors. Adv Pharmacol (2017) 80:207-21. doi:10.1016/bs.apha.2017. 03.005

156. Siuda ER, Carr R III, Rominger DH, Violin JD. Biased mu-opioid receptor ligands: a promising new generation of pain therapeutics. Curr Opin Pharmacol (2017) 32:77-84. doi:10.1016/j.coph.2016.11.007

157. Soergel DG, Subach RA, Burnham N, Lark MW, James IE, Sadler BM, et al. Biased agonism of the mu-opioid receptor by TRV130 increases analgesia and reduces on-target adverse effects versus morphine: a randomized, double-blind, placebo-controlled, crossover study in healthy volunteers. Pain (2014) 155:1829-35. doi:10.1016/j.pain.2014.06.011

158. Manglik A, Lin H, Aryal DK, Mccorvy JD, Dengler D, Corder G, et al. Structure-based discovery of opioid analgesics with reduced side effects. Nature (2016) 537:185-90. doi:10.1038/nature19112

159. Koblish M, Carr R III, Siuda ER, Rominger DH, Gowen-Macdonald W, Cowan CL, et al. TRV0109101, a G protein-biased agonist of the microopioid receptor, does not promote opioid-induced mechanical allodynia following chronic administration. J Pharmacol Exp Ther (2017) 362:254-62. doi:10.1124/jpet.117.241117

160. Dewire SM, Yamashita DS, Rominger DH, Liu G, Cowan CL, Graczyk TM, et al. A G protein-biased ligand at the mu-opioid receptor is potently analgesic with reduced gastrointestinal and respiratory dysfunction compared with morphine. J Pharmacol Exp Ther (2013) 344:708-17. doi:10.1124/ jpet.112.201616

161. Altarifi AA, David B, Muchhala KH, Blough BE, Akbarali H, Negus SS. Effects of acute and repeated treatment with the biased mu opioid receptor agonist TRV130 (oliceridine) on measures of antinociception, gastrointestinal function, and abuse liability in rodents. J Psychopharmacol (2017) 31:730-9. doi:10.1177/0269881116689257

162. Raehal KM, Bohn LM. The role of beta-arrestin2 in the severity of antinociceptive tolerance and physical dependence induced by different opioid pain therapeutics. Neuropharmacology (2011) 60:58-65. doi:10.1016/j. neuropharm.2010.08.003

163. Thompson GL, Kelly E, Christopoulos A, Canals M. Novel GPCR paradigms at the mu-opioid receptor. Br J Pharmacol (2015) 172:287-96. doi:10.1111/ bph. 12600

164. Le Merrer J, Becker JA, Befort K, Kieffer BL. Reward processing by the opioid system in the brain. Physiol Rev (2009) 89:1379-412. doi:10.1152/ physrev.00005.2009
165. Lalley PM. Mu-opioid receptor agonist effects on medullary respiratory neurons in the cat: evidence for involvement in certain types of ventilatory disturbances. Am J Physiol Regul Integr Comp Physiol (2003) 285:R1287-304. doi:10.1152/ajpregu.00199.2003

166. Schwarzacher SW, Rub U, Deller T. Neuroanatomical characteristics of the human pre-Botzinger complex and its involvement in neurodegenerative brainstem diseases. Brain (2011) 134:24-35. doi:10.1093/brain/ awq327

167. Farre M, Cami J. Pharmacokinetic considerations in abuse liability evaluation. Br J Addict (1991) 86:1601-6. doi:10.1111/j.1360-0443.1991.tb01754.x

168. Comer SD, Ashworth JB, Sullivan MA, Vosburg SK, Saccone PA, Foltin RW. Relationship between rate of infusion and reinforcing strength of oxycodone in humans. J Opioid Manag (2009) 5:203-12. doi:10.5055/jom. 2009.0022

169. Berkowitz BA. The relationship of pharmacokinetics to pharmacological activity: morphine, methadone and naloxone. Clin Pharmacokinet (1976) 1:219-30. doi:10.2165/00003088-197601030-00004

170. Sawynok J. The therapeutic use of heroin: a review of the pharmacological literature. Can J Physiol Pharmacol (1986) 64:1-6. doi:10.1139/y86-001

171. Ciccarone D, Ondocsin J, Mars SG. Heroin uncertainties: exploring users' perceptions of fentanyl-adulterated and -substituted 'heroin'. Int J Drug Policy (2017) 46:146-55. doi:10.1016/j.drugpo.2017.06.004

172. Bonhomme J, Shim RS, Gooden R, Tyus D, Rust G. Opioid addiction and abuse in primary care practice: a comparison of methadone and buprenorphine as treatment options. J Natl Med Assoc (2012) 104:342-50. doi:10.1016/ S0027-9684(15)30175-9

173. Jones JD, Sullivan MA, Vosburg SK, Manubay JM, Mogali S, Metz V, et al. Abuse potential of intranasal buprenorphine versus buprenorphine/naloxone in buprenorphine-maintained heroin users. Addict Biol (2015) 20:784-98. doi:10.1111/adb.12163

174. Gilbert IA, Regnard J, Lenner KA, Nelson JA, Mcfadden ER Jr. Intrathoracic airstream temperatures during acute expansions of thoracic blood volume. Clin Sci (Lond) (1991) 81:655-61. doi:10.1042/cs0810655

175. Elkader A, Sproule B. Buprenorphine: clinical pharmacokinetics in the treatment of opioid dependence. Clin Pharmacokinet (2005) 44:661-80. doi:10.2165/ 00003088-200544070-00001

176. Kuhlman JJ Jr, Lalani S, Magluilo J Jr, Levine B, Darwin WD. Human pharmacokinetics of intravenous, sublingual, and buccal buprenorphine. J Anal Toxicol (1996) 20:369-78. doi:10.1093/jat/20.6.369

177. Brown SM, Campbell SD, Crafford A, Regina KJ, Holtzman MJ, Kharasch ED. $\mathrm{P}$-glycoprotein is a major determinant of norbuprenorphine brain exposure and antinociception. J Pharmacol Exp Ther (2012) 343:53-61. doi:10.1124/ jpet.112.193433

178. Cobaugh DJ, Gainor C, Gaston CL, Kwong TC, Magnani B, Mcpherson ML, et al. The opioid abuse and misuse epidemic: implications for pharmacists in hospitals and health systems. Am J Health Syst Pharm (2014) 71:1539-54. doi:10.2146/ajhp140157

179. Dart RC, Surratt HL, Cicero TJ, Parrino MW, Severtson SG, Bucher-Bartelson B, et al. Trends in opioid analgesic abuse and mortality in the United States. N Engl J Med (2015) 372:241-8. doi:10.1056/NEJMsa1406143

180. Suzuki J, El-Haddad S. A review: fentanyl and non-pharmaceutical fentanyls. Drug Alcohol Depend (2017) 171:107-16. doi:10.1016/j.drugalcdep. 2016.11.033

181. Mather LE. Clinical pharmacokinetics of fentanyl and its newer derivatives. Clin Pharmacokinet (1983) 8:422-46. doi:10.2165/00003088-198308050-00004

182. Smith HS. Opioid metabolism. Mayo Clin Proc (2009) 84:613-24. doi:10.1016/ S0025-6196(11)60750-7

183. Schug SA, Ting S. Fentanyl formulations in the management of pain: an update. Drugs (2017) 77:747-63. doi:10.1007/s40265-017-0727-z

184. Jones CM. Heroin use and heroin use risk behaviors among nonmedical users of prescription opioid pain relievers - United States, 2002-2004 and 20082010. Drug Alcohol Depend (2013) 132:95-100. doi:10.1016/j.drugalcdep. 2013.01.007

185. Osborne R, Joel S, Grebenik K, Trew D, Slevin M. The pharmacokinetics of morphine and morphine glucuronides in kidney failure. Clin Pharmacol Ther (1993) 54:158-67. doi:10.1038/clpt.1993.127

186. Oldendorf WH, Hyman S, Braun L, Oldendorf SZ. Blood-brain barrier: penetration of morphine, codeine, heroin, and methadone after carotid injection. Science (1972) 178:984-6. doi:10.1126/science.178.4064.984 
187. Firestein GS, Budd R, Gabriel SE, Mcinnes IB, O’Dell JR. Kelley and Firestein's Textbook of Rheumatology E-Book. 10th ed. Elsevier (2017).

188. Brucker MC, King TL. Pharmacology for Women's Health. 2nd ed. J.a.B. Learning, editor. Burlington MA: Jones and Bartlett Learning (2017).

189. Vallner JJ, Stewart JT, Kotzan JA, Kirsten EB, Honigberg IL. Pharmacokinetics and bioavailability of hydromorphone following intravenous and oral administration to human subjects. J Clin Pharmacol (1981) 21:152-6. doi:10.1002/j. 1552-4604.1981.tb05693.x

190. Barakat NH, Atayee RS, Best BM, Ma JD, Jones JD, Sullivan MA, et al. Urinary hydrocodone and metabolite distributions in pain patients abuse potential of intranasal buprenorphine versus buprenorphine/naloxone in buprenorphine-maintained heroin users. J Anal Toxicol (2014) 38:404-9. doi:10.1093/jat/bku051

191. Toyama K, Uchida N, Ishizuka H, Sambe T, Kobayashi S. Single-dose evaluation of safety, tolerability and pharmacokinetics of newly formulated hydromorphone immediate-release and hydrophilic matrix extended-release tablets in healthy Japanese subjects without co-administration of an opioid antagonist. J Clin Pharmacol (2015) 55:975-84. doi:10.1002/jcph.501

192. Inturrisi CE. Clinical pharmacology of opioids for pain. Clin J Pain (2002) 18:S3-13. doi:10.1097/00002508-200207001-00002

193. Wright AW, Mather LE, Smith MT. Hydromorphone-3-glucuronide: a more potent neuro-excitant than its structural analogue, morphine-3-glucuronide. Life Sci (2001) 69:409-20. doi:10.1016/S0024-3205(01)01133-X

194. Coda BA, Rudy AC, Archer SM, Wermeling DP. Pharmacokinetics and bioavailability of single-dose intranasal hydromorphone hydrochloride in healthy volunteers. Anesth Analg (2003) 97:117-23. doi:10.1213/01.ANE. 0000066311.40978.4F

195. Ferrari A, Coccia CP, Bertolini A, Sternieri E. Methadone - metabolism, pharmacokinetics and interactions. Pharmacol Res (2004) 50:551-9. doi:10.1016/ j.phrs.2004.05.002

196. Preston KL, Epstein DH, Davoudzadeh D, Huestis MA. Methadone and metabolite urine concentrations in patients maintained on methadone. J Anal Toxicol (2003) 27:332-41. doi:10.1093/jat/27.6.332

197. Kilpatrick GJ, Smith TW. Morphine-6-glucuronide: actions and mechanisms. Med Res Rev (2005) 25:521-44. doi:10.1002/med.20035

198. Hasselstrom J, Sawe J. Morphine pharmacokinetics and metabolism in humans. Enterohepatic cycling and relative contribution of metabolites to active opioid concentrations. Clin Pharmacokinet (1993) 24:344-54.

199. Takala A, Kaasalainen V, Seppala T, Kalso E, Olkkola KT. Pharmacokinetic comparison of intravenous and intranasal administration of oxycodone. Acta Anaesthesiol Scand (1997) 41(2):309-12.

200. Lalovic B, Kharasch E, Hoffer C, Risler L, Liu-Chen LY, Shen DD. Pharmacokinetics and pharmacodynamics of oral oxycodone in healthy human subjects: role of circulating active metabolites. Clin Pharmacol Ther (2006) 79:461-79. doi:10.1016/j.clpt.2006.01.009

201. Lemberg KK, Siiskonen AO, Kontinen VK, Yli-Kauhaluoma JT, Kalso EA. Pharmacological characterization of noroxymorphone as a new opioid for spinal analgesia. Anesth Analg (2008) 106:463-70. doi:10.1213/ane. 0b013e3181605a15

202. Bostrom E, Simonsson US, Hammarlund-Udenaes M. In vivo blood-brain barrier transport of oxycodone in the rat: indications for active influx and implications for pharmacokinetics/pharmacodynamics. Drug Metab Dispos (2006) 34:1624-31. doi:10.1124/dmd.106.009746

203. Baylon GJ, Kaplan HL, Somer G, Busto UE, Sellers EM. Comparative abuse liability of intravenously administered remifentanil and fentanyl. JClin Psychopharmacol(2000)20:597-606.doi:10.1097/00004714-200012000-00002

204. Levine AI, Bryson EO. Intranasal self-administration of remifentanil as the foray into opioid abuse by an anesthesia resident. Anesth Analg (2010) 110:524-5. doi:10.1213/ANE.0b013e3181c5f069

205. Hoke JF, Cunningham F, James MK, Muir KT, Hoffman WE. Comparative pharmacokinetics and pharmacodynamics of remifentanil, its principle metabolite (GR90291) and alfentanil in dogs. J Pharmacol Exp Ther (1997) 281:226-32.
206. Christrup LL. Morphine metabolites. Acta Anaesthesiol Scand (1997) 41:116-22. doi:10.1111/j.1399-6576.1997.tb04625.x

207. Kitamura A, Higuchi K, Okura T, Deguchi Y. Transport characteristics of tramadol in the blood-brain barrier. J Pharm Sci (2014) 103:3335-41. doi:10.1002/jps.24129

208. Miyazaki T, Choi IY, Rubas W, Anand NK, Ali C, Evans J, et al. NKTR-181: a novel mu-opioid analgesic with inherently low abuse potential. J Pharmacol Exp Ther (2017) 363:104-13. doi:10.1124/jpet.117.243030

209. Webster L, Henningfield J, Buchhalter AR, Siddhanti S, Lu L, Odinecs A, et al. Human abuse potential of the new opioid analgesic molecule NKTR181 compared with oxycodone. Pain Med (2018) 19(2):307-18. doi:10.1093/ $\mathrm{pm} / \mathrm{pnw} 344$

210. Lipkowski AW, Konecka AM, Sroczynska I, Przewlocki R, Stala L, Tam SW. Bivalent opioid peptide analogues with reduced distances between pharmacophores. Life Sci (1987) 40:2283-8. doi:10.1016/0024-3205(87)90065-8

211. Toll L, Khroyan TV, Polgar WE, Jiang F, Olsen C, Zaveri NT. Comparison of the antinociceptive and antirewarding profiles of novel bifunctional nociceptin receptor/mu-opioid receptor ligands: implications for therapeutic applications. J Pharmacol Exp Ther (2009) 331:954-64. doi:10.1124/ jpet.109.157446

212. Zaveri NT, Jiang F, Olsen C, Polgar WE, Toll L. Designing bifunctional NOP receptor-mu opioid receptor ligands from NOP receptor-selective scaffolds. Part I. Bioorg Med Chem Lett (2013) 23:3308-13. doi:10.1016/j.bmcl.2013.03.101

213. Bird MF, Cerlesi MC, Brown M, Malfacini D, Vezzi V, Molinari P, et al. Characterisation of the novel mixed Mu-NOP peptide ligand dermorphin-N/OFQ (DeNo). PLoS One (2016) 11:e0156897. doi:10.1371/journal. pone. 0156897

214. Bloms-Funke P, Gillen C, Schuettler AJ, Wnendt S. Agonistic effects of the opioid buprenorphine on the nociceptin/OFQ receptor. Peptides (2000) 21:1141-6. doi:10.1016/S0196-9781(00)00252-7

215. Lutfy K, Eitan S, Bryant CD, Yang YC, Saliminejad N, Walwyn W, et al. Buprenorphine-induced antinociception is mediated by mu-opioid receptors and compromised by concomitant activation of opioid receptor-like receptors. J Neurosci (2003) 23:10331-7.

216. Vardanyan RS, Cain JP, Haghighi SM, Kumirov VK, Mcintosh MI, Sandweiss AJ, et al. Synthesis and investigation of mixed mu-opioid and delta-opioid agonists as possible bivalent ligands for treatment of pain. J Heterocycl Chem (2017) 54:1228-35. doi:10.1002/jhet.2696

217. Peterson CD, Kitto KF, Akgun E, Lunzer MM, Riedl MS, Vulchanova L, et al. Bivalent ligand that activates mu opioid receptor and antagonizes mGluR5 receptor reduces neuropathic pain in mice. Pain (2017) 158:2431-41. doi:10.1097/j.pain.0000000000001050

218. Khroyan TV, Cippitelli A, Toll N, Lawson JA, Crossman W, Polgar WE, et al. In vitro and in vivo profile of PPL-101 and PPL-103: mixed opioid partial agonist analgesics with low abuse potential. Front Psychiatry (2017) 8:52. doi:10.3389/fpsyt.2017.00052

219. Livingston KE, Stanczyk MA, Burford NT, Alt A, Canals M, Traynor JR. Pharmacologic evidence for a putative conserved allosteric site on opioid receptors. Mol Pharmacol (2018) 93:157-67. doi:10.1124/mol.117.109561

Conflict of Interest Statement: ALS and WW are in communication with Nektar Therapeutics. However, Nektar Therapeutics has had no input in this review.

The reviewer KL declared a shared affiliation, with no collaboration, with one of the authors, AS, to the handling Editor.

Copyright $\odot 2018$ Severino, Shadfar, Hakimian, Crane, Singh, Heinzerling and Walwyn. This is an open-access article distributed under the terms of the Creative Commons Attribution License (CC BY). The use, distribution or reproduction in other forums is permitted, provided the original author(s) and the copyright owner are credited and that the original publication in this journal is cited, in accordance with accepted academic practice. No use, distribution or reproduction is permitted which does not comply with these terms. 